\title{
Soviet Journalists at Nuremberg: Establishing the Soviet War Narrative
}

The Nuremberg IMT is usually thought to have performed a didactic function in part, as a kind of show trial. ${ }^{1}$ Given that the world public could not be in the courtroom, journalism had a key role to play in drawing lessons from the evidence. The largest group of journalists and writers ever gathered in one place to cover one event: over one hundred and sixty writers, ${ }^{2}$ as well as the artists and filmmakers who represented what happened there, all had a crucial role to play in mediating and distilling the lessons to be drawn from the nine month-long proceedings. While their interpretations have been supplemented and superseded by subsequent writings, memoirs and histories, as well as films, these contemporary journalistic reports played a crucial role in the struggle between competing understandings of the trial and the war.

The tension was a confrontation not only between those on trial and those trying them, but also between the victor nations administering justice. As discussed above (see Chapter Five), this encompassed the legal debates about what was or was not to be presented in the courtroom, and the roles of the various legal teams, and the many conflicts beneath the surface impression of common endeavour undertaken by United Nations, anticipated the emerging Cold War, ${ }^{3}$ or were its opening battle as the tribunal itself and the reporting of it became "the site and the subject of an immense propaganda struggle' ${ }^{4}$

In Western historiography, the USA is widely thought to have won the battle, so that the hegemonic view of the IMT may be summed up as 'a tale of liberal triumph' and 'a devastating propaganda failure' for the Soviets. ${ }^{5}$ This view has prevailed to such an extent that Western accounts often side-line the Soviets, whose presence 
inconveniently undermined the legal value of the trial, also introducing hard to pronounce names and difficult to understand motives. ${ }^{6}$ Such an approach distorts the picture by treating the Soviets' marginalization as a forgone conclusion, and largely silences the alternative Soviet account of the war and approach to the IMT that failed to gain hegemonic status. This simplification, in addition to reading the events through the distorting lens of their outcome, also underplays the Soviets' pivotal role in setting up the trial, and the significance of the evidence revealed by them, while simultaneously assuming the irrelevance of the Soviets' attempts to interpret the proceedings in line with their own emerging narrative of the war. ${ }^{7}$

Yet by defining and examining the evolution and distinct character of the Soviet account we can better understand not only why it failed and the Western account prevailed, but also grasp the extent to which it had merits and emphases missing from the dominant view of the IMT, some of which remain relevant to understanding Nazism and the Holocaust.

In broad terms the contemporary Soviet account of the IMT followed the formula of 'Russian exceptionalism, heroism and victimization' emphasizing the importance of the Soviet, and implicitly Russian, role in defeating the Nazis, of the suffering inflicted by the Nazis specifically on the Soviet people and talking up the Soviet role in the trial. ${ }^{8}$ Yet, despite the fact that all Soviet journalism underwent a process of preliminary censor's scrutiny to ensure unanimity on the overall narrative, a key distinguishing feature of the Soviet coverage, when compared with that of the American or British journalists, is that those covering the trial had far more experience as eyewitnesses of the most brutal of Nazi atrocities. The result was that, despite Soviet attempts to vet, centralize and standardize reporting, the tendency of a number of recent accounts of Soviet wartime journalism taken as a whole, when we 
look at the detail of specific articles and personalities, we see there are instances where individual reporters strove to retain their distinct voices and echo their personal histories. They necessarily refracted their courtroom perceptions not only through the overarching Soviet template and conventions for understanding the Nazis and the war, but also attempted to convey their own specific wartime positions as eyewitnesses to the immediate aftermath of Nazi mass murder, including the Holocaust. ${ }^{9}$ Of particular interest here is the Soviet writer and journalist Boris Polevoi in part because he was one of the only two Soviet journalists to publish an eyewitness account of Auschwitz on its liberation, at least in the central press, but also because he reworked that account in his reporting of the trial and again in his subsequent diaries and memoirs. The shifting emphases between these accounts are evident from a comparison of the different pieces by the same author on the same subject.

A further factor counteracting the homogenizing thrust of the Soviet leadership was that their own views on many of the issues were changing fast. Thus, the place of the war in the Soviet imaginary was shifting from the wartime patterns of representation and still unclear: the war had unleashed a 'plurality of narratives and actors' in the Soviet media, which could not be readjusted and standardized overnight. ${ }^{10}$ Thus, journalists' personal investments and the not yet fixed Soviet narrative on the war and Holocaust make Soviet journalistic coverage of the Nuremberg tribunal distinct, heterogeneous and a rewarding object for analysis.

\section{Conveying the Soviet Narrative}

The American prosecution team set out to steal everyone else's thunder at the courtroom itself, and ensure they played the central role, achieving this through a broad interpretation of the 'conspiracy' charge that meant using many of the documents supplied to them by the French, British and the Russians. This was part of 
a deliberate and largely successful attempt to keep 'the bulk of the case in American hands. ${ }^{11}$ Consequently other teams had good reason to be worried that this would make their interventions less dramatic and less telling, and they ultimately ended up repeating some of what the Americans had done, rather than cut down their cases, and this prolonged the trial needlessly. ${ }^{12}$ Necessarily, the first iteration of the Nazis' crimes was of greater interest than the subsequent ones, which presented the Soviet press with a difficult task: the Soviet narrative of the war cast the Soviet Union as the main character, and so Soviet coverage had to find a way to make the Soviets central, and overcome, at least to the satisfaction of domestic readers, the Americans' upstaging of them. ${ }^{13}$

First, however, Soviet journalists had to adapt their established wartime templates for understanding Nazism to the actual Nazi leaders physically present in front of them. In the first weeks of the trial particularly, it was the defendants themselves who attracted the most coverage, especially Göring, the 'Nazi number two,' and Hess, for his simulated memory loss. Even the American prison psychologist was writing a book intended from the outset as a scoop on the subject. ${ }^{14}$

The same fascination was evident in Soviet journalistic accounts. Yet, while they made some attempts to analyse the inner workings of the Nazi defendants, they were hampered by their established habits of representing the Nazi leaders in highly effective wartime caricatures. Seeing these people in the flesh forced a reappraisal of such portrayals: Polevoi was not alone in being struck by a sense that that Göring was not like his caricatures. ${ }^{15}$ As journalist and documentary filmmaker, Roman Karmen commented, cartoonists Boris Efimov and the Kukryniksy triumvirate of artists now had an opportunity to revise their caricatures: 
... for many years their sharp pencils and brushes have represented this band of Fascist leaders on caricatures and posters. Now for the first time they are drawing them from nature... ${ }^{16}$

Yet Efimov's cartoons continued the old habit of depicting the top Nazis as abnormal and monstrous. In a series entitled 'The Fascist Menagerie' Göring is depicted as a snake, Keitel as a jackal followed by a whole series of bestialized defendants. ${ }^{17}$ Likewise, the Kukryniksys' series of portraits of the defendants, used in pairs to accompany brief articles by writer Vsevolod Vishnevskii devoted to each of the defendants, emphasize Göring as cruel and greedy by showing him to be enormous and fleshy, in an echo of the classic early Bolshevik representations of capitalists as porcine. For grotesquely comic contrast, he is portrayed alongside an exaggeratedly skinny Hess. ${ }^{18}$ The combination of the Kukryniksys' caricatures and Vishnevskii's sketches do not always work well, since the grotesque mode is most effective when accompanied by a character sketch, but elsewhere Vishnevskii gives a biography and list of the crimes committed, which suggest these were the crimes of an inhuman system, rather than those of an exceptional individual.

One Soviet artist who attempted to depart from the established hyperbolic depictions was Nikolai Zhukov, whose sketches of the defendants strove to suggest moral corruption in a subtler, realist manner, as opposed to the Kukryniksy and Efimov):

When I looked from the figure of the chair of the court to the dock, I particularly felt their insignificance. They were not wearing prison clothes, they sat in their suits and ties, and in this they differed little from other people, and yet their Fascist essence, 
despite this, was clearly evident. Maybe people will think I'm biased, but I'm convinced that a truthful, realistic, successful drawing can in this case be more expressive in its damning force than caricature, because caricature is the hyperbolic use of physical shortcomings, extending them to the point they become funny. In such cases you never know what percentage of truth there is in this and how much artistic transformation. The Fascist criminals' appearance is such that an accurate copy of them was also the essence of their most unpleasant and negative character traits, whereas any exaggeration would be too much and a deviation from artistic truth. I could feel this intensely when I looked at the likes of Kaltenbrunner, Streicher, Hess etc. ${ }^{19}$

Zhukov's more subtle pencil drawings add literal and figurative shades of grey, suggesting an attempt to turn away from exceptional and monstrous portrayals, and to come to a more rounded appraisal of what the Nazis were, and how they came to do the things they did. The trial itself, through the conspiracy charge in particular, suggested an understanding of the individuals on trial as representatives of various organizations, i.e. of the Nazi state's component parts. Zhukov echoes the shift towards a sense of the unexceptional nature of the accused, which went together with an exploration of Nazism as a system. ${ }^{20}$

This reorientation had been present in Soviet coverage of the trial from the outset, that is, as early in proceedings as Pravda's leading article on the day the indictment was published in October 1945, which argued that it was not just individuals on trial but Fascism itself, and that the crimes were committed both by individuals and organizations. ${ }^{21}$ Influential Soviet legal expert Professor Aron Trainin had already written about the need for the trial as a means of achieving the 'moral and political 
defeat of Fascism." 22 To this end, the format of the trial enabled a more sophisticated understanding of the machinery of Nazi crimes, and shifted attention onto criminal organizations. Trainin explained that it was not just a question of establishing the guilt of the major Nazis, but of the organizations that they lead, to enable national courts to prosecute those found guilty of membership of those organizations. ${ }^{23}$ In a memorable turn of phrase, Lev Sheinin argued the trial was analogous to a 'pathologicalanatomical' clinical process - an autopsy on the corpse of Fascism attempting to find out how it functioned, and the reasons for its behaviour. The verdict would also be a diagnosis. $^{24}$

Yet, while Soviet commentators were willing to look at the systematic nature of the Nazi crimes, if this meant humanizing the defendants excessively, then they were unwilling to do so, as, in contrast with the other Allied treatments there was a greater distance to the defendants. Whereas a number of English language publications included interviews with the accused, the Soviets condemned the practice. ${ }^{25}$ Writer Leonid Leonov in particular criticized the international press for their obsession with Göring, and their recounting details such as his staring at a female member of the court staff, when scribes should have been taking an interest in the documents ${ }^{26}$ Vishnevskii was angered by a comment made by an 'Anglo-Saxon' neighbour, that Göring resembled Falstaff. He reacted, that despite his human failings, Falstaff was actually a human being: 'But Göring, the creator of German concentration camps... is he human at all?' For Vishnevskii, the answer is evidently, no. ${ }^{27}$ Leonov drew a different literary analogy, from Dostoevskii's Crime and Punishment to stress the Nazis' careful premeditation rather than irrational atavism: 'the clarity of thought of the murderer is striking: I doubt even Raskolnikov thought through his murder of the 
old woman so methodically." ${ }^{28}$ For the Soviets, of course, Russian literature was a more appropriate frame of reference for understanding the Nazis than Shakespeare.

The emphasis on the analysis of systems and organizations rather than individuals enabled the Soviets to highlight the role of the German army in carrying out Nazi policy, a connection the Western allies were reluctant to make. ${ }^{29}$ Indeed, they widely employ a translation of the Nazi term describing the invasion of the Soviet Union as a 'war of annihilation' (Vernichtungskrieg; voina na unichtozhenie), with its obvious parallels with extermination camps (Vernichstungslager). This has only recently been widely adopted by Western historians to describe the Eastern front. ${ }^{30}$ Semen Krushinskii expanded, rejecting the distinction that Keitel made between the German military and German Fascism: he argued that the corpses left by Einsatzgruppen who accompanied the Army's triumphant march across the Soviet Union are a clear illustration of this. ${ }^{31}$

While Soviet journalists' understandings of the Nazis evolved during the trial, they consistently viewed Nazism in such a way as to bolster the Soviet Union's own importance. One way of doing this was by stressing the anti-Communist component in National Socialism, and the own Nazis' use of the Bolshevik bugbear to distract democracies from their actions. ${ }^{32}$ Leonov distilled the Nazis' racist and anticommunist message to the German population: go to sleep and do not worry: 'Our long-range artillery and SS angels in azure raiments will guard your slumber from the Mongolo-Slavic-Jewish designs of Moscow."33

Throughout the presentation of the US, British and French evidence, the Soviet press reworked material so as to stress the centrality of the Soviets' own contribution and sacrifice in the war. One way of doing this was by the paratextual strategy of arranging material on the newspaper page, such as Pravda's setting of Vsevolod 
Vishnevskii's November piece on Germany's Anschluss with Austria, which makes no mention of the war on the Eastern front, alongside an article about operation Barbarossa by David Zaslavskii which included the word 'Barbarossa' prominently in its title. ${ }^{34}$

Soviet writers also shifted focus onto the Soviet experience by emphasizing the fate of Soviet victims and drawing comparisons from their own prior experience or other stories reported in the Soviet media: Erenberg, when commenting upon the Americans' detailed presentation of Nazi crimes, enumerates the earlier offences inflicted on the Soviets and exposed by the Soviet press as far back as 1942:

Volokalamsk, Istra, Kerch. ${ }^{35}$ Vishnevskii recounts the witness testimony of those called by the French, such as Marie-Claude Vaillant-Couturier's testimony about Auschwitz, but his article ends with these witnesses' account of the crimes committed against Russian prisoners of war. ${ }^{36}$ Roman Karmen does something similar when reporting the crimes committed at Dachau, concentrating on the Soviets killed there, going through the records to list their names. Having been part of the team filming Majdanek in autumn 1944, Karmen commented that Dachau differed little from Majdanek or Auschwitz, and that it was an extermination camp. ${ }^{37}$

Yet the most interesting and significant means whereby the Soviets insisted upon the centrality of their part in the war was through the supplementing of what was said or seen in the courthouse with personal memories summoned by the evidence. Thus, when watching footage of the American film, The Nazi Plan, Vishnevskii describes the terrible scenes these images stir, the evidence of Germany's use of slave labour elicits Vishnevskii's reflection upon the devastation and depopulation of the USSR, an evocation of the tears that lie behind the documents and causes Polevoi to address 
an article to the woman he met in Khar'kov in 1943, entreating her to stop crying now that her tormentors were facing justice. ${ }^{38}$

This sense of the Soviets as both the key participants and as crucial eyewitnesses was put forcefully by the leading article in Izvestiia on the day of the verdict:

The Soviet people, that have borne on their shoulders the main weight of the war of liberation against Fascism, know the Fascists' barbarous crimes not from hearsay accounts, and not from newspaper reports alone. With their own eyes Soviet people have seen the ruins of towns and the ashes of villages, with their own hands they have buried the corpses of those tortured and murdered. ${ }^{39}$

\section{The Soviet Journalist as Witness: Boris Polevoi}

The Nuremberg IMT deliberately played down the role of witnesses in favour of documents so as to establish a firm evidential base for the prosecution, and for the future historical record. ${ }^{40}$ This did little to enhance the drama and interest of the proceedings, and was one reason why they were often perceived as boring at the time. Leonov commented that time at Nuremberg was measured in the number of documents presented by the prosecution, and it provided 'food solely for the mind but not the heart." 41

A distinct feature of the Soviet journalists' accounts of the trial is that they try to reinsert the personal and emotive dimension widely perceived to be lacking from proceedings, and they do so by drawing on their extensive experience of wartime reporting, recalling the victims of Nazism they had encountered earlier on in the conflict. In doing so they may be seen to mobilize an inherent possibility of the act of testimony that it involves the person listening to the testimony in the original traumatic experience. ${ }^{42}$ While Lyndsey Stonebridge refers to the public intellectuals who were at the Nuremberg IMT as "secondary witnesses to Nazi crimes,"43 the 
Soviet journalists were witnesses of a more direct kind than this implies, having often been on the scene to see the immediate aftermath of Nazi atrocities earlier in the war, since 1941; most had seen far more sites of this kind, were closely related by language and culture to those whose fates and stories they witnessed, and consequently experienced a sense of co-owning the victims' testimony to their traumatic experiences at the hands of the Nazis. ${ }^{44}$ This meant that Soviet journalists were able to supplement the often arid proceedings with corroborating and enriching supplementary accounts. Polevoi's coverage of the trial is especially interesting in this respect, because he recalls his personal experience of Auschwitz: notably in an April 1946 article, entitled 'The Smoke of Auschwitz', where he refers to his visit to the camp, a day he will never forget: 'Auschwitz,' stated Polevoi, 'was the most monstrous of the Nazis' creations." 45

Few present at Nuremberg were able to grasp this fact, which has now become axiomatic to our understanding of the Holocaust. ${ }^{46}$ Polevoi, however, was alive to the meaning of testimony given at the trial by Auschwitz commandant Rudolf Franz Ferdinand Höss, and gave full credence to his boastful claims that Auschwitz was the place where the Nazis perfected the technology of destruction, because the Soviet journalist's experience at Auschwitz meant he was better able than almost anyone at the trial to make the distinction between labour and extermination camps, even if his article from Nuremberg, quoted below, mentioned Auschwitz and Mauthausen in the same breath. Indeed, this was a separation of functions he claims to have grasped already in his diary account of the original visit first to Auschwitz, when the Polish railway man with whom he was billeted explained that it was in fact Birkenau where the extermination function was conducted. ${ }^{47}$ 
Yet Polevoi's personal experience does not just sharpen his conceptual grasp as to the function of Auschwitz, it also adds an emotional tenor born from a sense of his being an eyewitness, of visiting Höss' personal quarters, and of seeing the dying prisoners:

I listen to the rustling of this calm and business-like voice [of Höss], and think what kind of system, environment, ideas there must be in which such monsters could be born, brought up and nurtured. I recalled the smoke of Auschwitz. I recalled its prisoners and their dying entreaties. And I wanted to say to those half-dead men in striped uniforms, who had been rescued from the fiery ovens by a miracle, that their murderer has not and will not escape punishment, and nor will all those who cultivated him, who directed his bloody hand who thought up all these Auschwitzes, Mauthausens, that there is no place for them on earth, there is none and will be none. $^{48}$

This ending of 'The Smoke of Auschwitz' echoed Polevoi's original publication from February 1945, which concluded with praise for the Red Army, for liberating the camp. It was also preceded by precisely the same arresting image of the cadaverous survivors he encountered at Auschwitz:

I saw those thousands of martyrs of Auschwitz - people exhausted to the point where they swayed like shadows in the wind, people whose age was impossible to guess. 
The Red Army saved them, toree them from hell. They praise the Red Army that has wrought vengeance on the Fascist executioners for Auschwitz, for Majdanek, and for all the pain and suffering they have caused the peoples of Europe. ${ }^{49}$

In comparing the two articles we sense an evolution: in Polevoi's initial newspaper report he had stressed its provisional nature, the sense that his report would necessarily not be able to grasp the full picture, just as Simonov had at Majdanek, and the British and American reporters were later to do in the camps they discovered. ${ }^{50} \mathrm{We}$ might note here that Polevoi does not mention the Jewish identity of the overwhelming majority of the camp's victims.

However, Polevoi's original, unpublished 29 January 1945 report to herticulates asense the Army Political Directorate, who effectively exercised censorship, has now been released from the Russian Ministry of Defence archive to mark the $70^{\text {th }}$ anniversary of Nazism as his description of the 'conveyor of death' shows:

This was a long building, almost half a system. In both his article at the time, and that published at Nuremberg, the image of the camp's inmates as a haunting presence dominates the conclusion, and it is these prisoners who are made to articulate its central message. A cynical attitude to Soviet propaganda might say that this exploits their image: the Soviets' shrill emotional pitch contrasts with the prevailing, drily legal, tone of the Tribunal, yet it also harks back to the Moscow show trials, and both their hysteria and concomitant lack of concern for legal process. ${ }^{51}$ But while that is part of what is happening, the image of camp survivors also seems to be one that truly haunted Polevoi, making his report so poignant: it was his burden as a witness to life in the camp in the aftermath of liberation. This same combination of propagandist 
motives and fresh first-hand experience was present in Soviet reporting of the Soviet prosecution case.

\section{The Soviet Prosecution}

Soviet coverage of the trial was initially extensive, with a leading article on the front page of Pravda on the day the indictment was announced, a further two pages detailing it, and a laconic TASS report on proceedings. Throughout the first months the Soviet press contained opinion pieces by author-journalists, sometimes as many as three or four on a single day. However, Soviet attention began to stray despite the efforts of reporters to inflect the other prosecution team's presentations so as to underscore the Soviet perspective: Vishnevskii even claims that when chief prosecutor for the Soviet Union, Roman Rudenko spoke in December to counter efforts made by the defence, "even the American guards put their headphones on." 52 As the Soviet press began to lose interest many reporters returned home at Christmas and the coverage began to dwindle to the telegraphic TASS summaries in January. This was interrupted on 9 February 1946, when once more there appeared a three and a half-page verbatim report in Pravda and Izvestiia, this time of Rudenko's opening speech.

The remaining Soviet journalists now made a renewed effort to stimulate interest in the trial, stressing the vital importance, and dramatic effect, of the Soviet evidence. This was the opportunity they had been waiting for to articulate the Soviet perspective on events. They did this first of all by heralding Rudenko as expressing the "voice of the Soviet people." 53 Polevoi argued that this intervention made the Soviet achievement in saving humanity from Nazism clearer to all than it had been previously: 
Although the court already possessed documents of extraordinary strength, until today, in the courtroom during the Soviet prosecutor's speech, never yet had the image of Fascism unfolded before it with such breadth, the blood-drenched designs of Fascism had never yet been exposed before it so fully, and those present at the trial had never yet grasped with such strength of conviction the mortal danger from which the Red Army and our Soviet state had saved humanity. ${ }^{54}$

The Soviet prosecution then presented evidence including its own films, including one of Nazi atrocities, and a series of witnesses to substantiate their narrative of the trial. The Soviet journalists present made sure that the emotional power and underlying political message of this testimony was spelt out to their readers.

\section{The Soviet Witnesses}

Polevoi's articles stressed the impact on the trial of the Soviet witnesses' testimony, writing that: 'their strength and significance made a profound impression." 55 The Soviet journalists certainly did their best to ensure that this would be the case, and spent considerable energies recounting the experience of these witnesses: Russian peasant Iakov Grigoriev, Academic Orbeli (director of the Hermitage museum in Leningrad, who was also a member of the Soviet war crimes commission), Evgenii Kivil'sha, a Ukrainian military doctor, Auschwitz eye-witness Severina Shmaglevskaia and survivor of the Vilnius ghetto, Abram Sutskever. ${ }^{56}$ Nikolai Zhukov likewise drew portraits of these same witnesses.

Each of these people had suffered personally at the hands of the Nazis, and consequently the effect was to heighten the emotional atmosphere. As Soviet journalist Semen Krushinskii put it, the words of these witnesses, such as 
Smaglevskaia's address to the accused: 'where are our children?' were not part of the legal process but nevertheless much needed simple and righteous words. ${ }^{57}$

Along with intensifying the emotional pitch, the Soviets were also trying, in calling these witnesses, and especially Sutskever, to Sovietize the narrative of the trial, trying to do so by showing evidence of the crimes against the Jewish people, but presenting it in such a way as to emphasize the Soviets' role in ending this suffering, and play down independent Jewish resistance. ${ }^{58}$

\section{Jewish Dimension}

In view of the Soviet Union's later anti-Semitism, and near silence over the Holocaust, it may seem surprising that Soviet journalists such as Erenburg mentioned the figure of 6 million Jews killed by the Nazis and that both he and Vishnevskii refer to the Nazi description of this as the 'solution of the Jewish question,' a phrase here quoted by Vishnevskii as being used by Göring in a personal letter to architect of the Holocaust, Reinhard Heydrich. ${ }^{59}$ Yet, while the destruction of Europe's Jews was reported by the Soviet press covering the trial, the harrowing account of Sutskever, one of only 600 Jews to have survived in Vilnius, from an original population of 80,000 , is retold so as to stress that he was helped to escape by Soviet partisans. ${ }^{60}$

The same message is evident when Polevoi discusses Governor General of occupied Poland, Hans Frank's diary, mentioning Jews far less, but once again ending with emphasis on the fact that it was the Red Army, with the help of the United Nations, that saved the world from the likes of Frank. ${ }^{61}$

When, Polevoi wrote a piece about the Stroop report on the destruction of the Warsaw ghetto, which he incorrectly entitles the 'Stumpf' report, and describes the annihilation of the Warsaw ghetto in terrifying detail, describing the showing of photographs from the report, and the Nazis' own film made of the destruction of the 
ghetto. He makes no attempt to dissemble the Jews' fate. ${ }^{62}$ However, Polevoi's account is completely silent as to the 1943 Warsaw ghetto uprising: the Jews are not said to have resisted, but rather to have attempted to escape, or to have preferred death in the flames to death at the hands of the Nazis. The ghetto uprising, as an independent Jewish initiative that bore no relation to the Red Army, and did not cast the Soviet Union as the key agent of Nazi defeat, was evidently not worth mentioning for Polevoi.

Subsequently, Polevoi further 'sovietized' this evidence in his memoirs by moving the description of the Stroop report (now spelled correctly) to Soviet prosecutor Smirnov's evidence, and the opening of the Soviet prosecution, giving Smirnov some of the lines describing the elegantly bound volume that he used in the newspaper article in December $1945 .{ }^{63}$ The effect of this rewriting of history is to undo some of the scene stealing by the Americans during the trial, by placing the evidence back in Soviet hands.

\section{The Soviet Films}

A further tool the Soviet team used to convey a sense of their own narrative of the war was the screening of films compiled from Soviet newsreel footage of the aftermath of Nazi occupation. Strangely, however, these films attracted less attention, even from Soviet journalists than the earlier footage shown by the US prosecution, which had a sensational and much discussed impact. The problem seems to have been that by the time the Soviet films were shown, most of the Soviet journalists had lost interest in the trial, and there were few reports about it in the Soviet press. Indeed, the same is true of their coverage of the Soviet prosecution's production of star witness Field Marshall Von Paulus, who had surrendered to the Red Army at 
Stalingrada, an event that is treated in many accounts as the highpoint of the Soviet case, but that was not covered in Pravda or Izvestiia at the time. ${ }^{64}$

Izvestiia's report on the main film shown by the Soviets, Film Documents of Atrocities Committed by the German-Fascist Invaders (Kinodukumenty o zverstvakh nemetsko-fashistskikh zakhvatchikov) written by Roman Karmen, who had a hand in making the film itself, tended to rehash the film's content. However, it also stressed the Soviets' role in pushing for the trial, in collating film evidence since 1941, and in fulfilling their 'great mission of liberation". ${ }^{65}$ While the gruesome film with its catalogue of corpses, whom Karmen describes as 'mute witnesses', does not itself directly articulate this message of the Soviet role, its timeframe, geographical emphasis, and the very fact that it was made and shown by the Soviets, all draw attention to their role in the trial. ${ }^{66}$ The conviction that this film footage too was a form of witness testimony was one deeply held by Karmen, who had not only overseen its compilation but also filmed some of the footage.

Echoing descriptions of the films screened by the US prosecution, which concentrated on the shocked reactions of the defendants, Karmen claims that the Soviet film distressed them more than at any previous point in the proceedings, and turned their faces pale with fear. This is corroborated by Ann and John Tusa's history of the trial: 'The film surpassed in horror anything yet shown, anything envisaged from the evidence which had yet been heard." 67

In addition to Film Documents of Atrocities..., the Soviets showed a number of films at the trial, including a captured German film showing the destruction of the Czech town of Lidice, which Krushinskii describes, but the emphasis is upon the suffering inflicted by the Nazis upon the Soviet people, and the attempted destruction of the Russian nation in particular. This is the underlying message of the Soviet film 
showing Nazi destruction of sites of cultural value in the USSR, and another one recording the destruction of Soviet towns. Krushinskii comments that, for all its importance, such film 'is only able to represent the full extent of the Nazis' crimes in the way that a test-tube full of sea water represents the sea." 68 Yet while a case can be made for the importance of these Soviet films, they failed to attract the attention the films shown by the US did. ${ }^{69}$

\section{The Evolving Political Situation}

Despite the impression created by Soviet journalists, the Soviet prosecution did not have much of an effect on a trial that was already regarded as at best tedious and at worst irrelevant, both in the USSR and beyond. Tensions between the United Nations outside the courtroom were rising. Throughout the trial, Soviet journalists made noises complaining about the toleration of Nazi sympathizers in Britain, where Oswald Mosley was said to be on the march again, about former Nazis being still at liberty to sell pro-Nazi literature in British-controlled West Germany and about the fact that the remnants of the German Army were under British jurisdiction in Schleswig-Holstein. ${ }^{70}$

The implication was that Britain as a whole had pro-Hitler sympathies, and that the only true opponents of the Nazis were the Soviets. In a variation on this theme, Vishnevskii argued the defence interventions were an attempt to use the tribunal as a forum to inspire wider Fascist views, and cites examples of these expressed in Britain. ${ }^{71}$

The simmering hostility boiled over when Winston Churchill made his 5 March 1946 speech, in Fulton, Missouri, where he condemned the Soviet Union's crushing of democracy in Eastern Europe. ${ }^{72}$ The front-page Pravda editorial described this as nothing other than the 'liquidation' of the United Nations. ${ }^{73}$ Later that year Pravda 
published an article entitled 'The Kiss of Goebbels' written by David Zaslavskii, which argued that Churchill's Fulton speech was inspired by Goebbels. ${ }^{74}$ The Cold War adversaries were beginning to see each other as similar to the Nazis.

If the participants did not previously understand that the Cold War was breaking out, then they began to now. With the Soviet Union realizing that it had effectively been outmanoeuvred in legal, diplomatic and propaganda terms, and therefore had little to gain from the trial any more, the journalistic coverage was allowed to dwindle to a minimum, with almost no cartoons, and very few authored articles, including none at all in May and June. Polevoi began devoting his energies to the writing of a novel The Story of a True Man, which even took him back to Moscow for several months in spring. ${ }^{75}$

Only towards the very end of the trial did it become newsworthy once more, as in August, after an absence of anything other than TASS reports for months, the Soviet press published a lengthy verbatim report of chief prosecutor for the USSR, Rudenko's closing speech, covering most of a folio page. ${ }^{76}$ There was further coverage at the end of August and beginning of September, concentrating on Rudenko's speeches, and on the day of the verdict, there was a leader and the verbatim reproduction of it, followed by, on $5^{\text {th }}$ October, a lengthy condemnation of the judgment, criticizing the innocent verdict on Papen, Schacht and Frickk, and also on the imprisonment and not death sentence handed to Hess. ${ }^{77}$

The Cold War mood was signalled by the Izvestiia leader on the day of the verdict, which argued that the defence and defendants were aided by their supporters in the Vatican and the Hearst media empire. ${ }^{78}$ Inside the Soviet Union, the final moments of the trial were accompanied by the ideological retrenchment led by Andrei Zhdanov and many of its targets related to the themes raised at Nuremberg. First of all, in 
August, prominent journals (Zvezda) and writers (Mikhail Zoshchenko and Anna Akhmatova) associated with Leningrad were criticized, implicitly for their independence of mind and their city's independence of action during the war. Then in September a film A Great Life [Bol'shaia zhizn'] part 2 was criticized for its unacceptably frank depiction of the occupation..$^{79}$ The ambiguities and deviations from the Stalinist norm during the war were now becoming a major source of embarrassment, and since the trial necessarily touched upon them, as well as showing the erstwhile Western allies in a good light, and unacceptably highlighting the fate of the Jews, it was becoming an ever more unwelcome and sensitive subject. The war was now to be remembered primarily as a glorious, unproblematic, overwhelmingly Soviet victory. Writers, journalists or filmmakers unable to articulate that vision adequately were to be censured.

\section{Conclusion}

The Soviet press coverage at Nuremberg attempted to present the proceedings in such a way as to highlight Soviet wartime losses, their part in the victory and their role as arbiters of the post-war order. However, the way in which Soviet reports of the trial ebbed away into near silence seems to corroborate accounts of the Soviets' participation in the trial as a failure. Hirsch sees Soviet failures as linked to the centralized nature of their propaganda and as a consequence of being institutionally and politically outmaneuvered. ${ }^{80}$

While it is hard to dispute that the Soviets were outmanoeuvred, or that their propaganda system's overall centralization was a hindrance, when we look at particular themes, such as the depiction of the Nazis, or particular journalists' reworking of material they had already covered, such as Polevoi on Auschwitz, we see an illuminating picture of someone grappling with the problem of fitting hisould 
could own experiences and thoughts into the emerging template for representation of the trial.

The result is that, while the Soviet reporting all servedd centralized propagandist aims, at its best, it combinedd this overarching purpose with a poignant tone of emotional immediacy, with the candour of the reporters' personal experiences and eyewitness accounts to the worst of the Nazi atrocities. Given that the trial more broadly side-lined witnesses in favour of documents, the Soviet accounts may be said to add something of a corrective to the dull prevailing course of the tribunal. These personal memories were the main reason why, in some instances the Soviets anticipated modern views on the importance of Auschwitz as a site of the Holocaust, and on the nature of the Wehrmacht's complicity in the 'war of annihilation' and hence the Holocaust in the USSR.

But it is also true that the Soviets' failure to convey their narrative convincingly to the wider world, especially the Western powers present at Nuremberg, was due to the difficulties Soviet propaganda faced in adapting its domestic methods to the international sphere: what worked in the USSR did not work so well at Nuremberg. ${ }^{81}$ While the focus of this chapter has been Soviet journalism aimed at a domestic readership, it is evident that even in attempting to make the trial corroborate the emerging Soviet narrative of the war to this constituency there were problems, since the trial's Western and American bias was hard to redress. This challenge for Soviet journalists at Nuremberg pointed to the wider problem for the Soviets in the post-war period, where their stressing of the price paid by the Soviets for victory was not properly recognized abroad, and Nuremberg was one of the first indications of the Soviets' impending defeat in the Cold War battle over the memory of World War Two. Indeed, Geoffrey Roberts argues that one of the factors driving the anti-Western 
campaign and the initial stages of the Cold War was genuine indignation from Stalin that the West did not recognize sufficiently the Soviet contribution to the war with concrete diplomatic concessions. ${ }^{82}$

Ultimately, however, the trial itself was addressed, as Polevoi surmised, not to contemporaries, but to posterity ${ }^{83}$ If this is so, then we can productively revisit it and decide for ourselves what evidence, which documents and what testimony was the most important. By doing so I believe we shall increasingly decide that the Soviet evidence and media presence has been undervalued.

${ }^{1}$ Francine Hirsch, "The Soviets at Nuremberg: International Law, Propaganda, and the Making of the Postwar Order," American Historical Review, 113:3 (June 2008), 701-30 (p. 713).

${ }^{2}$ William J. Bosch, Judgment on Nuremberg: American Attitudes Toward the Major German War-Crime Trials, Chapel Hill: University of North Carolina Press, 1970, p. 94.

${ }^{3}$ Joseph E. Perisco, Nuremberg: Infamy on Trial, London: Penguin, 1995, pp. x-xi.

${ }^{4}$ Hirsch, "The Soviets at Nuremberg," pp. 703, 722.

${ }^{5}$ Hirsch, "The Soviets at Nuremberg," pp. 701, 703.

${ }^{6}$ See, for example, Perisco, Nuremberg: Infamy on Trial: this account stresses the Soviet attitudes as simply to be overcome to achieve a just trial and uses no Russian language sources.

${ }^{7}$ On Soviets' legal input see Hirsch, "The Soviets at Nuremberg," passim.

${ }^{8}$ James V. Wertsch, Voices of Collective Remembering, Cambridge University Press, 2002, p. 106.

${ }^{9}$ For an account of Soviet wartime reporting as overwhelmingly centralized, see:

Berkhoff (, Motherland in Danger: Soviet Propaganda During World War II, Cambridge, MA: Harvard University Press, 2012 Hirsch also argues this with regard to Nuremberg, and sees this centralization as the reason for the Soviets' defeat in propaganda terms: (Hirsch, "The Soviets at Nuremberg," p. 728).

${ }^{10}$ Jeffrey Brooks, Thank You, Comrade Stalin: Soviet Public Culture from Revolution

to Cold War, Princeton, N.J.: Princeton University Press, 2000, p. 193.

${ }^{11}$ Chief prosecutor, Robert Jackson, quoted in Tusa and John Tusa, The Nuremberg

Trial, London and Basingstoke: Macmillan, 1983: 175).

12 Tusa and Tusa, The Nuremberg Trial, p. 175.

${ }^{13}$ Wertsch compares Soviet and post-Soviet Russian textbooks' narratives of the war, stressing that they all place the USSR at the centre of their narratives. Wertsch, Voices of Collective Remembering, pp. 106-12

${ }^{14}$ Persico, Nuremberg: Infamy on Trial, p. x.

${ }^{15}$ Boris Polevoi, Sobranie sochinenii, 9 Vols, Commentary N. Zheleznova, Moscow: Khudozhestvennaia literatura, 1981, vol. 8, p. 448

${ }^{16}$ Roman Karmen, "Iz zala suda," Izvestiia, 28 November 1945, p. 3. 
${ }^{17}$ Boris Efimov, "Fashistskii zverinets. Iz zala suda," Izvestiia, 5 December 1945, p. 4.

${ }^{18}$ Vsevolod Vishnevskii, Kukryniksy, "Na Niurembergskom protsesse. Ikh portety," Pravda, 5 December 1945, p. 4.

${ }^{19}$ Nikolai Zhukov, "Niurnbergskii protsess. Reportazh khudozhnika N. Zhukova," in Boris Polevoi, V kontse kontsov. Niurnbergskie dneviki. Zarisovki Nikolaia Zhukova, $2^{\text {nd }}$ edn, Moscow: Sovetskaia Rossiia, 1972, p. 247.

${ }^{20}$ Anon., "Germanskii fashizm pered sudom narodov," Pravda, 19 October 1945, p. 1.

${ }^{21}$ Anon., "Germanskii fashizm pered sudom narodov," Pravda, 19 October 1945, p. 1.

${ }^{22}$ Aron Trainin, "Mezhdunarodnyi voennyi tribunal," Pravda, 11 August 1945, p. 4.

${ }^{23}$ Aron Trianin, "Prestupnye organizatsii gitlerizma," Pravda, 23 December 1945, p. 3.

${ }^{24}$ Lev Sheinin, "Nemye svideteli," Izvestiia, 2 December 1945, p. 3.

${ }^{25}$ For an example of condemnation of the practice of interviewing the Nazis, see: Vishnevskii, "Nichego ne zabyto!" Pravda, 17 December 1945, p. 4

${ }^{26}$ Leonid Leonov, "Liudoed gotovit pishchu," in Leonid Leonov, V nashi gody.

Publitsistika 1941-1948, Moscow: Sovetskii pisatel', 1949, 175-85 (p. 176).

(Original: Pravda, 10 December, 1945).

${ }^{27}$ Vsevolod Vishnevskii, “Iz zala suda," Pravda, 6 December 1945, p. 3.

${ }^{28}$ Leonid Leonov, "Liudoed gotovit pishchu," p. 177.

${ }^{29}$ Sergei Krushinskii, “'Otkroveniia' bitogo polkovodtsa,” Izvestiia, 6 April 1946, p. 4.

${ }^{30}$ The term "war of annihilation" features as the title of a chapter, in, for example, Geoffrey Roberts, Stalin's Wars: From World War to Cold War, 1939-1953, New Haven and London: Yale University Press, 2006.

${ }^{31}$ Krushinskii, “"Otkroveniia' bitogo polkovodtsa,” p. 4.

32 Vsevolod Vishnevskii, "V Niurnberge," Pravda, 26 November 1945, p. 4.

${ }^{33}$ Leonov, "Liudoed gotovit pishchu", pp. 180-81.

${ }^{34}$ David Zaslavskii, "Razboinichnyi 'plan Barbarossa,"” Pravda, 30 November 1945.

p. 3; Vsevolod Vishnevskii, "Terror i provokatsii - oruzhie gitlerizma," Pravda, 30

November 1945, p. 3.

${ }^{35}$ Il'ia Erenburg, "Chas otveta," Izvestiia, 4 December 1945, p. 3.

${ }^{36}$ Vsevolod Vishnevskii, “Govoriat svideteli, govoriat ochevidtsy...” Pravda, 1 February 1946, p. 5.

${ }^{37}$ Karmen, "Palachi Dachau,", p. 4. Curiously, this is not strictly true: for all its horrors, Dachau was never intended to exterminate inmates on arrival, a point that Polevoi made when he visited it. Whereas the US and British tendency was to downplay death camps by seeing them through the prism of Concentration Camps, the Soviets did precisely the opposite, and exaggerated the importance of the Concentration Camps by eliding them with the extermination function. Thus Karmen says that no one ever left Dachau: in fact they did. Polevoi, Sobranie sochinenii, Vol. 8, p. 390.

38 Vsevolod Vishnevskii, "Gitlerovskii plan agressii na ekrane," Pravda, 13 december 1945, p. 3; Vsevolod Vishnevskii, "Na gitlerovskoi katorge," Pravda, 15 December 1945, p. 3; Boris Polevoi, "Ne plach'te bol'she, Mariia!," Pravda 13 December 1945, p. 4 
${ }^{39}$ Anon., "Prigovor gitlerizmu," Izvestiia, 2 October 1946, p. 1.

${ }^{40}$ Persico, Nuremberg: Infamy on Trial, pp. 43, 92; Annette Wieviorka, The Era of the Witness, trans. from French by Jared Stark, Ithaca and London: Cornell University Press, 2006 [orig. L'Ère du témoin, 1998], p. 68. Donald Bloxham argues that this led to the trial failing to engage a wider public with the facte of the victims. Donald Bloxham, Genocide on Trial: War Crimes Trials and the Formation of Holocaust History and Memory, Oxford: Oxford University Press, 2001, p. 152.

41 "Liudoed gotovit pishchu" p. 175. Curiously, very similar words were used by the chief prosecutor at the Adolf Eichmann trial. See: Wieviorka, The Era of the Witness, p. 83.

42 Dori Laub, "Bearing Witness of the Vicissitues of Listening," in Shoshana Felman and Dori Laub, Testimony: Crises of Witnessing in Literature, Psychoanalysis, and History, New York and London: Routledge, 1992, 57-74 (p. 57).

${ }^{43}$ Lyndsey Stonebridge, The Judicial Imagination: Writing After Nuremberg, Edinburgh: Edinburgh University Press, 2001, p. 8.

${ }^{44}$ Laub, "Bearing Witness of the Vicissitues of Listening," p. 57. It should however, be noted that, Martha Gelhorn, who was also at Nuremberg was one of the first journalists to enter Dachau: Stonebridge, The Judicial Imagination, p. 5. Although she does not refer to Soviet examples, Marilyn B. Meyers refers to the journalistic accounts written at the time of liberation as "acts of witnessing.": Marilyn B. Meyers, "Historic and Psychic Timeline: Opening and Closing the Space for Witnessing," in Nancy R. Goodman and Marilyn B. Meyers (eds), The Power of Witnessing: Reflections, Reverberations, and Traces of the Holocaust, New York and London: Routledge, 2012, (27-43) p. 35

${ }^{45}$ Boris Polevoi, "Dym Osventsima," Pravda, 19 April 1946, p. 3.

${ }^{46}$ Bloxham, Genocide on Trial, pp. 103-04.

${ }^{47}$ However, Polevoi's diary was only published years later, and we cannot be sure he did not rework it after the war. Likewise, when Polevoi recounts the testimony of Smaglevskaia in his later published diary, he is able to contextualize it because knows that the Birkenau camp was the epicentre of the killing, and the place where enormous numbers of children were murdered. Polevoi, Sobranie sochinenii, Vol. 8: 130-31, 394.

${ }^{48}$ Polevoi, "Dym Osventsima," p. 3.

${ }^{49}$ Boris Polevoi, "Kombinat smerti v Osventsime," Pravda, 2 February 1945, p. 4.

${ }^{50}$ Polevoi, "Kombinat smerti v Osventsime," p. 4. For a discussion of Simonov's use of this trope in the representation of Majdanek see: Jeremy Hicks, "'Too gruesome to be fully taken in': Konstantin Simonov's 'The Extermination Camp' as Holocaust Literature", The Russian Review 72 (April 2013), 242-59.

${ }^{51}$ There were a number of such echoes, such as the poet Maksim Ryl'skii referred to the accused as rabid dogs" and the sudden appearance of the Soviet prosecutor whose favourite phrase that was, Andrei Vyshinskii, who proposed a toast, at an official function, to the speedy death of the defendents. Maksim Ryl'skii, "Sud," Izvestiia, 20 October 1945, p. 2; Tusa and Tusa, The Nuremberg Trial, p. 232.

${ }^{52}$ Vsevolod Vishnevskii, "Nichego ne zabyto!" Pravda, 17 December 1945, p. 4.

${ }^{53}$ Boris Polevoi, "Pomni ob etom, izbiratel'," Pravda, 9 February 1946, p. 5.

${ }^{54}$ Polevoi, "Pomni ob etom, izbiratel"," p. 5.

${ }^{55}$ Boris Polevoi, "Ot imeni chelovechestva," Pravda, 4 March 1946, p. 4. 
56 Polevoi, "Ot imeni chelovechestva," p. 4; Sergei Krushinskii, "Sud'ba tsivilizatsii," Izvestiia, 24 February 1946, p. 4; Sergei Krushinskii, "Prostye slova," Izvestiia, 1 March 1946, p. 3.

${ }^{57}$ Krushinskii, "Prostye slova,", p. 3.

${ }^{58}$ For a discussion of Soviet wartime media representations of the Holocaust, see: Berkhoff, Motherland in Danger, pp. 134-66; Hicks, First Films of the Holocaust, passim.

${ }^{59}$ Il'ia Erenburg, "Kontrataka nochi," Izvestiia, 30 March 1946, p. 3; Vsevolod Vishnevskii, "Podsudimye i svideteli," Pravda, 7 January 1946, p. 3.

${ }^{60}$ Polevoi, "Ot imeni chelovechestva," p. 4; Krushinskii, "Prostye slova," Izvestiia, p. 3.

${ }^{61}$ Boris Polevoi, 'Vot on, 'novyi poriadok!'’ Pravda, 18 February 1946, p. 3.

${ }^{62}$ Boris Polevoi, "Kniga v kozhe," Pravda, 16 December 1945, p.3.

${ }^{63}$ Polevoi, Sobranie sochinenii, Vol. 8, p. 346.

${ }^{64}$ However, Polevoi discusses the incident in his diary/memoir, subsequently translated into English. Polevoi, Sobranie sochinenii, Vol. 8, pp. 427-35.

${ }^{65}$ Roman Karmen, "Mertvye obviniaiut," Izvestiia, 20 February 1946, p. 3.

${ }^{66}$ Persico, Nuremberg: Infamy on Trial, pp. 244-48. Polevoi writes no piece about it at the time, but discusses it at length in his diary adding eyewitness details to substantiate and expand on the film.

Polevoi, Sobranie sochinenii, Vol. 8, pp. 416-17.

${ }^{67}$ Tusa and Tusa, The Nuremberg Trial, p. 198.

${ }^{68}$ Sergei Krushinskii, "Sud'ba tsivilizatsii," Izvestiia, 24 February 1946, p. 4.

${ }^{69}$ For a more extended discussion of Film Documents of Atrocities see: Hicks, First Films of the Holocaust, pp. 186-95.

${ }^{70}$ Lev Sheinin, "Prizraki zagovorili..." Izvestiia, 22 December 1945, . 3; Leonov, "Liudoed gotovit pishchu" p. 185; David Zaslavskii, "Pozemel'e fashistskikh prestupnikov," Pravda, 31 December 1945, p.5; Il'ia Erenburg, "Kontrataka nochi," Izvestiia, 30 March 1946, p. 3; David Zaslavskii, "Volch'ia golova i volchii khvost," Pravda, 1 December 1945, p. 3.

${ }^{71}$ Vsevolod Vishnevskii, "Vylazki gitlerovskikh posledyshei," Pravda, 21 December 1945 , p. 4.

${ }^{72}$ Hirsch discusses impact of Churchill's speech, presented during the Soviet prosecution, Hirsch, "The Soviets at Nuremberg," pp. 719-21.

73 Anon, "Cherchill' briatsaet oruzhiem," Pravda, 11 March 1946, p. 1.

${ }^{74}$ David Zaslavskii, “Lobyzanie Gebbel'sa,” Pravda 1 August 1946, p. 4.

${ }^{75}$ Polevoi, Sobranie sochinenii, Vol. 8, pp. 455-58.

76 'ZZakliuchitel'nnaia rech' Glavnogo Obvinitelia ot SSSR tov. R. A. Rudenko, Pravda, 1 August 1946, p. 3; Pravda 2 August 1946, p. 2; Pravda 3 August 1946, p.

2; Pravda 4 August 1946, p. 3; Pravda 5 August 1946, pp. 2-3.

77 "Osoboe mnenie chlena Mezhdunarodnogo Voennogo Tribunala ot SSSR t.

Nikitchenko op povodu resheniia Tribunala," Pravda 5 October, 1946. p. 3 .; 6

October 1946, p. 3.

78 Anon., "Prigovor gitlerizmu," Izvestiia, 2 October 1946, p. 1.

${ }^{79}$ B. Suchkov, "Protiv bezideinykh I falæ shivykh kinofil'mov," Pravda 11

September 1946, p. 2.

${ }^{80}$ Hirsch, "The Soviets at Nuremberg," p. 726.

${ }^{81}$ Hirsch, "The Soviets at Nuremberg," p. 728.

${ }^{82}$ Roberts, Stalin's Wars: From World War to Cold War, pp. 331-32.

${ }^{83}$ Polevoi, Sobranie sochinenii, Vol. 8, p. 523. 